University of Nebraska - Lincoln

DigitalCommons@University of Nebraska - Lincoln

Faculty Publications from the Center for Plant

Science Innovation

Plant Science Innovation, Center for

$5-25-2007$

\title{
Dicamba Resistance: Enlarging and Preserving Biotechnology- Based Weed Management Strategies
}

\author{
Mark Behrens \\ University of Nebraska - Lincoln \\ Nedim Mutlu \\ University of Nebraska - Lincoln, nmutlu2@unl.edu \\ Sarbani Chakraborty \\ University of Nebraska - Lincoln \\ Razvan Dumitru \\ University of Nebraska - Lincoln \\ Wen Zhi Jiang \\ University of Nebraska - Lincoln, wjiang2@unl.edu \\ See next page for additional authors
}

Follow this and additional works at: https://digitalcommons.unl.edu/plantscifacpub

Part of the Plant Sciences Commons

Behrens, Mark; Mutlu, Nedim; Chakraborty, Sarbani; Dumitru, Razvan; Jiang, Wen Zhi; LaVallee, Bradley J.; Herman, Patricia L.; Clemente, Thomas E.; and Weeks, Donald P., "Dicamba Resistance: Enlarging and Preserving Biotechnology-Based Weed Management Strategies" (2007). Faculty Publications from the Center for Plant Science Innovation. 31.

https://digitalcommons.unl.edu/plantscifacpub/31

This Article is brought to you for free and open access by the Plant Science Innovation, Center for at DigitalCommons@University of Nebraska - Lincoln. It has been accepted for inclusion in Faculty Publications from the Center for Plant Science Innovation by an authorized administrator of DigitalCommons@University of Nebraska Lincoln. 


\section{Authors}

Mark Behrens, Nedim Mutlu, Sarbani Chakraborty, Razvan Dumitru, Wen Zhi Jiang, Bradley J. LaVallee, Patricia L. Herman, Thomas E. Clemente, and Donald P. Weeks 
Published in Science 316 (May 25, 2007), pp. 1185-1188; doi 10.1126/science.1141596 Copyright (C) 2007 American Association for the Advancement of Science. Used by permission. http://www.sciencemag.org/cgi/content/full/316/5828/1185/DC1

Submitted February 21, 2007; accepted April 23, 2007.

\section{Dicamba Resistance: Enlarging and Preserving Biotechnology-Based Weed Management Strategies}

Mark R. Behrens, ${ }^{1 *}$ Nedim Mutlu, ${ }^{1 *}$ Sarbani Chakraborty, ${ }^{1}$ Razvan Dumitru, ${ }^{1}$ Wen Zhi Jiang, ${ }^{1}$ Bradley J. LaVallee, ${ }^{2 \dagger}$ Patricia L. Herman, ${ }^{1 \ddagger}$

Thomas E. Clemente, ${ }^{2,3,4}$ Donald P. Weeks ${ }^{1,4}$

${ }^{1}$ Department of Biochemistry, ${ }^{2}$ Center for Biotechnology, ${ }^{3}$ Department of Agronomy and Horticulture, ${ }^{4}$ Plant Science Initiative, University of Nebraska-Lincoln, Lincoln, NE 68588, USA.

* These authors contributed equally to this work. ${ }^{\dagger}$ Present address: Monsanto Company, St. Louis, MO U.S.A. ₹ Present address: School of Biological Sciences, University of Nebraska-Lincoln, Lincoln, NE 68588, USA. Corresponding author - D. Weeks, dweeks1@unl.edu

Abstract: The advent of biotechnology-derived, herbicide-resistant crops has revolutionized farming practices in many countries. Facile, highly effective, environmentally sound, and profitable weed control methods have been rapidly adopted by crop producers who value the benefits associated with biotechnology-derived weed management traits. But a rapid rise in the populations of several troublesome weeds that are tolerant or resistant to herbicides currently used in conjunction with herbicide-resistant crops may signify that the useful lifetime of these economically important weed management traits will be cut short. We describe the development of soybean and other broadleaf plant species resistant to dicamba, a widely used, inexpensive, and environmentally safe herbicide. The dicamba resistance technology will augment current herbicide resistance technologies and extend their effective lifetime. Attributes of both nuclear- and chloroplast-encoded dicamba resistance genes that affect the potency and expected durability of the herbicide resistance trait are examined.

$\mathrm{I}^{1}$ $\mathrm{n}$ the past decade, the availability of biotechnology-derived herbicide-resistant and insect-resistant traits has led to striking advancements in agricultural crop management systems throughout the world. These "input traits" have contributed to greater productivity per hectare, decreased production costs, greater flexibility and efficiencies in production regimes, reduced pesticide use, and improved farmer health (1-3). In 2006, more than 100 million hectares worldwide were planted with crops having biotechnology-derived traits (4). In the United States, for example, Roundup (glyphosate)-resistant crops were planted on almost $90 \%$ of the soybean acreage and $60 \%$ of the cotton acreage in 2005, along with about $18 \%$ of the corn crop (3). The recent emergence of weeds resistant to the herbicides used year after year for weed control in fields of herbicide-resistant crops has prompted serious concerns regarding the long-term availability of the facile and economically important weed control provided by current herbicide-resistant crop plants. Also at risk is the greatly expanded use of no-till or reduced-till planting procedures that are made possible by "burndown" of weeds before planting of herbicide-resistant crops. These integrated practices minimize soil loss due to water and wind erosion resulting from traditional methods of soil tillage (3).

Among the glyphosate-tolerant weed species currently posing the greatest danger to agricultural productivity are several broadleaf plants such as giant ragweed (Ambrosia trifida), horseweed (Conyza canadenis), waterhemp (Amaranthus rudis), Palmer amaranth
(Amaranthus palmeri), and common ragweed (Ambrosia artemisifolia) $(3,5)$. To combat these pernicious weeds and to address the potential emergence of other herbicideresistant broadleaf weeds, we have targeted the development of crop plants resistant to treatment with dicamba. Dicamba is a widely used, low-cost, environmentally friendly herbicide that does not persist in soils and shows little or no toxicity to wildlife and humans (6-10). Use of the dicamba resistance trait alone or in combination with other herbicide resistance traits will allow rotation of herbicides or use of mixtures of herbicides that will greatly suppress several present or future herbicide-resistant weeds. Here, we describe the use of a genetically engineered bacterial gene, DMO (dicamba monooxygenase), that encodes a Rieske nonheme monooxygenase capable of inactivating dicamba when expressed from either the nuclear genome or chloroplast genome of transgenic plants. The DMO enzyme acts

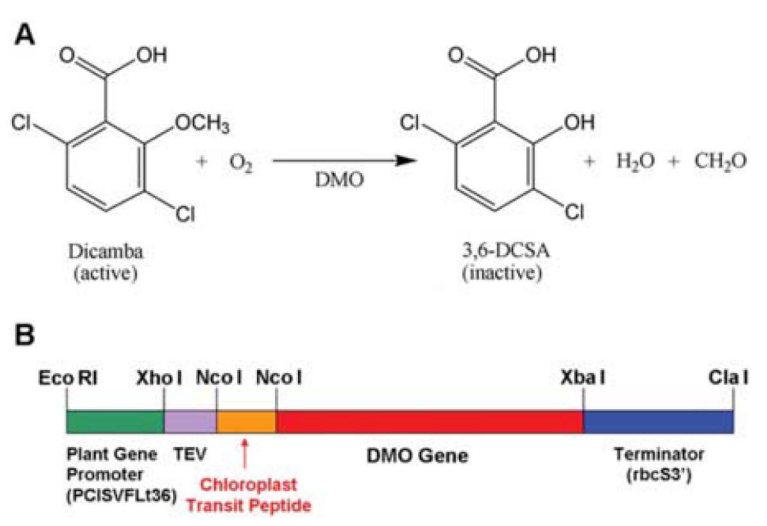
dicamba. to destroy the herbicidal activity of dicamba before the herbicide can build to toxic levels in dicamba-treated transgenic plants, as shown below.

As the first step in the complete mineralization of dicamba, the soil bacterium Pseudomonas maltophilia (strain DI-6) converts dicamba to 3,6-dichlorosalicylic acid (DCSA) $(11,12)$ (Figure 1A), a compound that lacks appreciable herbicidal activity. The enzyme system responsible for this conversion in the bacterium is the threecomponent enzyme dicamba $O$-demethylase. This enzyme system serves as an electron transfer chain in which electrons from $\mathrm{NADH}$ (the reduced form of nicotinamide adenine dinucleotide) are shuttled through a reductase to a ferredoxin and finally to the terminal component DMO (13-15). The ferredoxin component of dicamba $\mathrm{O}$-demethylase closely resembles the ferredoxin found in plant chloroplasts. Thus, to potentially take advantage of a source of reduced ferredoxin in chloroplasts of transgenic plants to supply electrons for the DMO reaction (and to eliminate the need for the bacterial reductase and ferredoxin genes), we included a chloroplast transit peptidecoding region upstream of the DMO gene to allow targeting of DMO to the chloroplast. The DMO expression cassette (Figure 1B) contained the strong peanut chlorotic streak virus gene promoter FLt36 (16) and a terminator region from the pea Rubisco (ribulose-1,5-bisphosphate carboxylase-oxygenase) small subunit gene. The goal then was to determine whether expression of DMO from this expression vector in transgenic broadleaf plants could provide protection against the normally lethal effects of

Because of ease of transformation and regeneration, Arabidopsis thaliana, tomato, and tobacco were used as model systems to test whether expression of the DMO gene alone (i.e., without the ferredoxin and reductase components of dicamba O-demethylase) could impart herbicide resistance after application of dicamba. Agrobacterium-mediated gene transfer was used to introduce the DMO expression cassette into the nuclear genome of the respective plant species. In regard to tobacco, we used DNA, RNA, and protein blot analyses to test several independently derived $\mathrm{T}_{1}$-generation

Figure 1. Dicamba inactivation. (A) Conversion of dicamba to DCSA by DMO. (B) Genetically engineered version of the DMO gene for expression in higher plants, using the FLt36 promoter from peanut chlorotic streak virus, a translational enhancer from the tobacco etch virus (TEV), a chloroplast transit peptidecoding region from the pea Rubisco small subunit gene for chloroplast localization of $\mathrm{DMO}$, and a terminator region from the pea Rubisco small subunit gene ( $r b c S 3)$. 
plants for the presence and expression of the $D M O$ gene (Figure S2). RNA blots demonstrated highly variable levels of DMO mRNA in individual transformants that, in general, did not correlate closely with the amount of DMO enzyme produced. We noted (most easily in lanes 2 and 6, Figure S2) that although most of the precursor DMO molecule containing the chloroplast transit peptide was cleaved to the mature form, not all of the precursor was processed.

Most dicotyledonous plants, such as tobacco, are quite sensitive to treatment with dicamba, an auxin-type herbicide. Figure 2A illustrates this point by showing nontransgenic tobacco plants not treated (leftmost plant) and treated with increasing amounts of dicamba. Herbicide damage symptoms are pronounced after spraying dicamba even at the low level of $0.017 \mathrm{~kg} /$ ha. Symptoms are quite severe at $0.28 \mathrm{~kg} /$ ha and $0.56 \mathrm{~kg} / \mathrm{ha}$, the levels normally used for weed control in agricultural applications.

Treatment of transgenic tobacco plants containing the $D M O$ gene with $5.6 \mathrm{~kg} / \mathrm{ha}$ (10 to 20 times the recommended application rate) caused few if any symptoms, whereas a nontransgenic plant suffered severe damage (Figure 2B). Damage to the lower leaves of the transgenic plants could be duplicated by spraying plants with the surfactant-containing solvent solution used as the vehicle for dicamba application. Leaves produced after treatment of the transgenic plants with dicamba exhibited no visible signs of damage (Figure 2C). Transgenic tomato plants carrying the genetically engineered $D M O$ gene, likewise, showed no damage to newly emerged leaves (Figure S2B) after spraying with dicamba at concentrations as high as 5.6 $\mathrm{kg} / \mathrm{ha}$. Arabidopsis expressing the DMO gene also displayed strong resistance to treatment with dicamba at $1.12 \mathrm{~kg} / \mathrm{ha}$, the highest level tested (Figure S3). Over a range of dicamba concentrations tested, an unexpected finding was the observation that tobacco plants transformed with a DMO expression cassette lacking a transit peptide-coding region were resistant to treatments with dicamba at levels on average only slightly below that of plants containing $D M O$ genes bearing transit peptide-coding regions (Figure S4; see below).

To determine whether DMO could function exclusively inside chloroplasts, we created the pDMO1 vector bearing the DMO gene coding region (Figure S5). This vector allows integration of the DMO gene into the chloroplast genome of tobacco by homologous recombination and the isolation of transformants through selection for antibiotic resistance. The DMO gene coding region was driven by the strong $p s b A$ chloroplast gene promoter, containing the complete $p s b A$ 5'-untranslated region sequence, to obtain high levels of DMO expression. Initial DNA blot analyses of antibiotic-resistant transgenic plants (Figure $\mathrm{S6A}$ ) demonstrated the presence in chloroplast genomes of both the DMO transgene (5.6-kb band) and the native $p s b A$ gene re- gion (3.3-kb band). Repeated regeneration and selection of transgenic plants on antibiotic-containing medium resulted in apparently homoplastidic chloroplasts bearing the $D M O$ gene fragment but not the endogenous native gene region (Figure S6B). Only chloroplast transformants expressing the DMO enzyme were resistant to treatment with dicamba (Figure S7). $\mathrm{T}_{1}, \mathrm{~T}_{2}$, and $\mathrm{T}_{3}$ generations of progeny from two independently derived chloroplast transformants were tested for resistance to treatment with dicamba at various doses. All exhibited high levels of resistance. Indeed, chloroplast genome transformants displayed no apparent amage (other than "solvent-only damage" to lower leaves) when sprayed with dicamba at a rate of $28 \mathrm{~kg} /$ ha (Figure S8). Only transitory damage was observed when plants were treated with extremely high dicamba applications of 112 and $224 \mathrm{~kg} / \mathrm{ha}$. At these extremely high levels, initial damage was caused primarily by surfactants and other components of the solvent in which dicamba was delivered. New apex tissues and leaves growing from the damaged plants displayed nearly normal to normal phenotypes, showed no decrease in growth rates, and retained the ability to produce usual numbers and quality of seeds.

The above results were consistent with the hypothesis that reduced ferredoxin in tobacco chloroplasts could be the donor to DMO of electrons needed for oxidation of dicamba to DCSA. As a direct test of this hypothesis, we examined the ability of purified spinach ferredoxin to support the
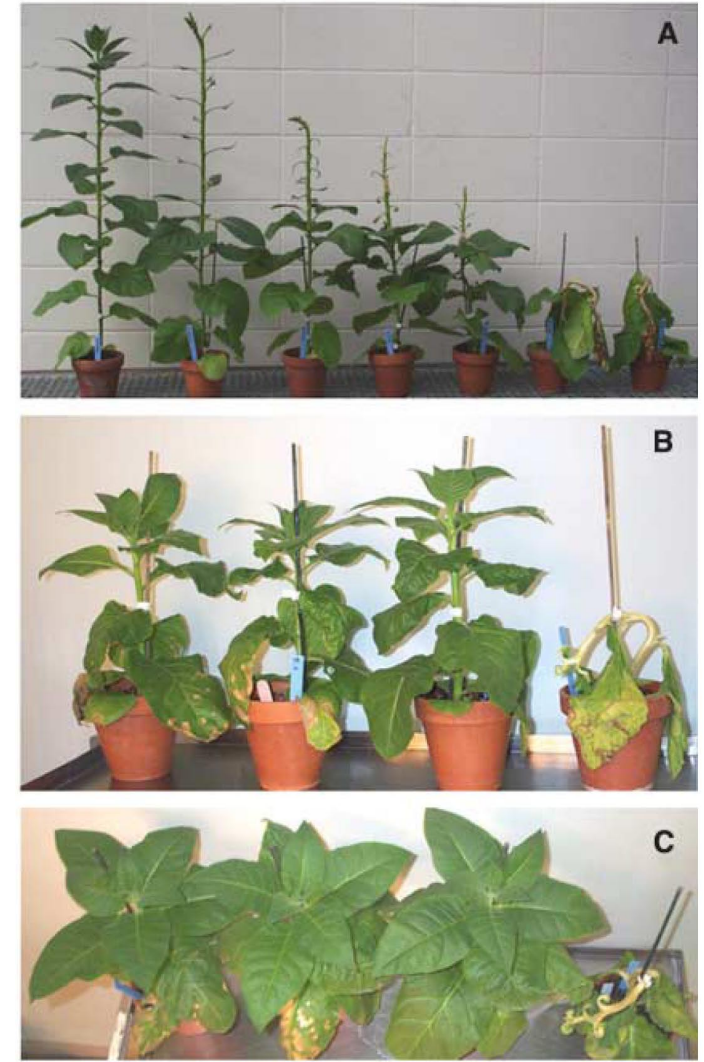

Figure 2. Effects of dicamba treatment on nontransgenic tobacco plants and plants transformed with a genetically engineered DMO gene. (A) Demonstration of the sensitivity of nontransgenic tobacco plants to treatment with increasing doses of dicamba (left to right: $0,0.017,0.034,0.07,0.14$, 0.28 , and $0.56 \mathrm{~kg} / \mathrm{ha}$ ). (B) Three independently derived $\mathrm{T}_{1}$-generation tobacco plants carrying the dicamba resistance gene (three plants at left) and a nontransgenic plant (right) treated with dicamba at a level of $5.6 \mathrm{~kg} / \mathrm{ha}$. (C) Top view of plants in (B). 
case of plants carrying DMO as a nuclear gene (Table S3). Most plants examined by DNA blot analysis contained a single DMO gene insert. Moreover, $\mathrm{T}_{3}$ and $\mathrm{T}_{4}$ progeny maintained the original levels of expression in regard to herbicide resistance whether they contained single or multiple copies of the DMO gene.

The prime value of the dicamba resistance technology is related to its use in major field crops in which management of broadleaf weeds is essential to maximize production. Because soybean is one such crop, we transformed the soybean varieties Thorne (Ohio State University) and NE3001 (University of Nebraska) with the same DMO expression cassette (Figure 1B) used to transform tobacco, tomato, and Arabidopsis. As a means to derive marker-free soybean transformants, a two-T-DNA binary plasmid was assembled. In this plasmid, the marker-gene T-DNA element carried a bar gene cassette under the control of the Agrobacterium tumefaciens nopaline synthase promoter (nos), and the second, separate, T-DNA element carried the DMO expression cassette. More than 50 transgenic soybean events were produced, and seeds from the $T_{1}, T_{2}$, and $T_{3}$ generations were collected. Among the population of primary transformants generated, one markerfree event was identified that harbored only the DMO cassette. Most transgenic soybean events showed resistance to treatment with dicamba at $2.8 \mathrm{~kg} / \mathrm{ha}$ and $5.6 \mathrm{~kg} / \mathrm{ha}$ under greenhouse conditions (Figure S9) and complete resistance to dicamba at $2.8 \mathrm{~kg} /$ ha (the highest level tested in field trials) (Figure 3). Initial field studies with five independent soybean events on University of Nebraska farms over the past 3 years revealed no compromise in agronomic performance-including yield, date to flowering, height, and lodging - in the transgenic plots treated with dicamba application (1.5 $\mathrm{kg} / \mathrm{ha}$ ) at preplant, V3 stage, or dual preplant spray treatment coupled with postemergence treatments at the V3 stage of plant development when compared with non-herbicide-treated, weed-free plots of the parental soybean variety Thorne.

Dicamba resistance in all of the plants tested did not require cotransformation with either ferredoxin or reductase genes from P. maltophilia (strain DI-6). These results showed that the plants contained one or more molecules that could transfer the

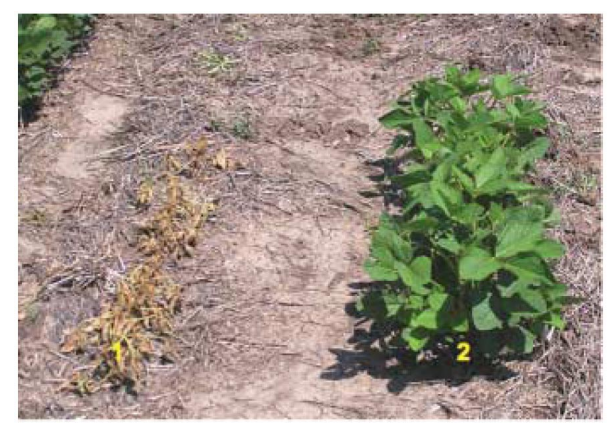

requisite electrons to $\mathrm{DMO}$ to allow conversion of dicamba to DCSA. The initial targeting of DMO to the chloroplasts by means of a transit peptide sequence was aimed at using reduced ferredoxin abundantly available in the chloroplasts. However, transformation of tobacco plants with a DMO gene construct lacking a chloroplast transit peptide-coding sequence unexpectedly resulted in plants that were highly resistant to treatment with dicamba. Results from our limited trials with a small number of $\mathrm{T}_{1}$-generation plants indicated that the level of resistance obtained with these transgenic plants was only slightly lower on average than that obtained with tobacco plants producing DMO containing a transit peptide.

These observations raise important questions in regard to the molecules in transgenic plants that can productively donate electrons to DMO. The fact that homoplastidic chloroplasts producing DMO internally from a $D M O$ gene integrated into the chloroplast genome show resistance to extremely high levels of dicamba (Figure S8) and the fact that purified DMO can function in vitro with reduced spinach chloroplast ferredoxin (Table S2) both suggest that chloroplast ferredoxin can productively interact with DMO to allow electron transfer. However, the source of electrons for DMO produced from nuclear genes lacking a chloroplast transit peptide-coding sequence remains unknown. Presuming that ferredoxins do not reside outside of the plant chloroplasts, one must consider the possibility that an unknown cytoplasmic protein can provide DMO with a steady supply of electrons. Alternatively, DMO itself might contain a gratuitous chloroplast transit peptide that allows sufficient DMO to enter the chloroplasts to provide protection from dicamba moving into the cell after dicamba treatment. Further studies, such as microscopic localizations in situ of DMO with and without a chloroplast transit peptide and/or isolation and identification of cytoplasmic proteins that can interact "indiscriminately" with DMO to supply electrons, will be needed to resolve the questions emanating from the present observations.

It is illuminating to consider that dicot plants like tobacco display distinct injury symptoms even at levels of dicamba treatment as low as 0.001 to $0.01 \mathrm{~kg} / \mathrm{ha}$ (Figure 2A). Many transgenic tobacco, tomato,

Figure 3. Effects of dicamba treatments on nontransgenic soybean plants and transgenic plants containing the genetically engineered $D M O$ gene. Nontransgenic (1) and transgenic soybean plants (2) treated under field conditions with dicamba at a level of $2.8 \mathrm{~kg} / \mathrm{ha}$ are pictured 8 days after spraying.
Arabidopsis, and soybean plants containing a nuclear-encoded DMO gene were fully resistant to treatments with dicamba at or above $5.8 \mathrm{~kg} / \mathrm{ha}$. This demonstrates that the DMO gene, present even in a single copy and expressed at relatively moderate rates (table S2), is capable of decreasing the sensitivity of dicot plants to applications of dicamba by at least a factor of 5000 .

Dicamba is an "auxin"-type herbicide that mimics the effects of excess quantities of the natural plant hormone indole-3-acetic acid (IAA) when applied to dicotyledonous plants. It has been used for more than 40 years to efficiently control most broadleaf weeds. Yet despite its widespread use, no new noxious and economically important dicamba-resistant weed species have appeared (5). One possible reason for such a situation may be that dicamba may act on some, if not all, of the IAA receptors that are essential in controlling normal growth and development of all plants. If so, the appearance of new dicamba-resistant weeds may not happen rapidly. This is especially true if the dicamba resistance gene is "stacked," for example, with the widely used glyphosate resistance gene to allow farmers to alternate herbicide applications between dicamba and glyphosate or to use mixtures of the two herbicides together. In either case, appearance of weeds resistant to either dicamba or glyphosate will be greatly suppressed. Moreover, the ability to use either or both herbicides before planting or at a variety of points during crop development will allow producers excellent weed control with greater flexibility in their crop management practices. This may be particularly important in the control of existing glyphosate-resistant weeds, such as horseweed, in which application of dicamba before planting can control emerged or emerging glyphosate-resistant weeds. Thus, dicambaresistant crops can be a valuable asset in strategies to control currently existing herbicide-resistant weeds and to suppress the appearance of additional herbicide-resistant weeds that ultimately could threaten the long-term use and value of current herbicides and herbicide-resistant crops. Likewise, dicamba-resistant crops should further encourage the use of conservation tillage practices that greatly decrease soil erosion and foster more sustainable and environmentally friendly farming.

\section{References and Notes}

1. F. Hossain et al., Int. J. Occup. Environ. Health 10, 296 (2004).

2. J. Huang, R. Hu, S. Rozelle, C. Pray, Science 308, 688 (2005).

3. A. L. Cerdeira, S. O. Duke, J. Environ. Qual. 35, 1633 (2006).

4. International Service for the Acquisition of Agri-biotech Applications, Global Status of Commercialized Biotech/ GM Crops: 
2006; see executive summary at http:// www.isaaa.org/resources/publications/ briefs/35/executivesummary/default.html

5. International Survey of Herbicide Resistant Weeds; http://www.weedscience.org/ in.asp

6. J. T. Stevens, D. D. Sumner, in Handbook of Pesticide Toxicology, W. J. Hayes, E. R. Laws Jr., Eds. (Academic Press, New York, 1991), pp. 1317-1408.

7. Herbicide Handbook (Weed Science Society of America, Champaign, IL, ed. 7, 1994).

8. Hazardous Substance Databank (U.S. National Library of Medicine, Bethesda, MD, 1995).

9. Health Advisory Summary: Dicamba (Office of Drinking Water, U.S. Environmental Protection Agency, Washington, DC, 1988).

10. Extoxnet Pesticide Information Profiles: Dicamba; http://extoxnet.orst.edu/pips/dicamba.htm .
11. D. J. Cork, J. Kreuger, Adv. Appl. Microbiol. 36, 1 (1991).

12. J. Yang, X.-Z. Wang, D. Hage, P. Herman, D. Weeks, Anal. Biochem. 219, 37 (1994)

13. P. L. Herman et al., J. Biol. Chem. 280 , 24759 (2005).

14. S. Chakraborty et al., Arch. Biochem. Biophys. 437, 20 (2005).

15. X. Wang, B. Li, P. L. Herman, D. Weeks, Appl. Environ. Microbiol. 63, 1623 (1997).

16. I. B. Maiti, R. Shepherd, Biochem. Biophys. Res. Commun. 244, 440 (1998).

17. P. Maliga, Photochem. Photobiol. Sci. 4 , 971 (2005).

18. N. Dufourmantel et al., Plant Mol. Biol. 55, 479 (2004).

19. We thank M. Fromm for helpful suggestions regarding the manuscript; L. Allison for the kind gift of the chloroplast transformation vector pFMDV1 and for assistance with chloroplast transformation techniques; G. Graef for seeds of the soybean variety NE3001; and K. Horkey for precise applications of dicamba to greenhouse-grown plants. Dicamba monooxygenase (DMO; oxygenaseDIC) is GenBank accession number AY786442 (ddmC). Supported by the Consortium for Plant Biotechnology Research, United AgriProducts, the Monsanto Company, and the University of Nebraska Agricultural Research Division. D.P. Weeks and P.L. Herman hold a patent entitled "Methods and Materials for Making and Using Transgenic DicambaDegrading Organisms." D.P. Weeks, T.E. Clemente, M. Behrens, P.L. Herman, and $\mathrm{N}$. Mutlu will receive royalties from the marketing of dicamba-resistant technology if crop seeds containing the resistance gene are marketed by Monsanto, the licensee of this technology from the University of Nebraska. 


\section{Supporting Material}

MATERIALS AND METHODS:

Reagents and Standard Methods: Restriction and other enzymes were obtained from either Fermentas or Invitrogen. DIG-11-dUTP (alkali-labeled), CSPD (ready-to-use), DIG III molecular weight markers, anti-digoxigenin-AP (Fab fragments) and blocking reagent were obtained from Roche.

Prehybridization solution, ULTRAhyb was obtained from Ambion. The molecular weight marker DIG-RNA molecular weight marker I, was obtained from Roche. Anti-rabbit lgG, peroxidase-linked antibody (donkey) and Hybond ECL (nitrocellulose) membrane were obtained from Amersham Biosciences. DNA, RNA and Protein blots, recombinant DNA techniques, and other molecular biology procedures were carried out using standard protocols (13).

Cloned Genes, Existing Vectors and New Vector Construction:

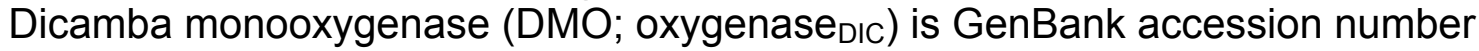
AY786442 (ddmC). Vectors pRTL2 (12) and pKLP36 were used in creating a DMO gene construct with and without a DNA sequence encoding an upstream Rubisco small subunit transit peptide from pea. The pKLP36 binary vector (9) was obtained from Dr. Indu Maiti from the University of Kentucky. A DMO W112C variant coding sequence (DMOc) was initially generated by PCR amplification from a wild-type DMO gene (DMOw) template. In this amplification, the coding region of DMOw was amplified from the plasmid pPLH1, which contained the DMOw gene as a $3.5 \mathrm{kbp}$ Xho I/Sst I fragment of $P$. maltophilia, strain DI-6, DNA (6). For DNA amplification, a 5' primer was employed that inserted an Nco I restriction site near the $5^{\prime}$ end of the PCR product and a codon for alanine immediately following the ATG initiation codon. A 3' primer was used that created an Xba I restriction site at the $3^{\prime}$ end of the PCR product (primer sequences provided below). The $112 \mathrm{~W}$ to $112 \mathrm{C}$ change in the resulting DMOc gene was subsequently identified by nucleic acid sequencing.

For creation of the plant transformation vector, pKLP36-TEV-TP-DMOc, the DMOc gene was inserted using Nco I and Xba I sites added to the 5' and 3' ends, respectively, of the coding region into the pRTL2 vector (12) thereby fusing the transit peptide coding region to the vector's tobacco etch virus (TEV leader) translation enhancer element. As noted above, the 5' Nco I site was introduced along with the addition of a GCC codon (alanine) following the ATG start codon and an Xba I restriction site was created at the 3 ' end of the codon region using PCR primers (Oxy-Nco I 5'- ggagcagcccatggccttcgtccgcaatg -3'; Oxy-Xba I 5' atgccccagtctagaatatcgccgggaca $-3^{\prime}$ ). To allow potential delivery of DMOc to the chloroplast, the chloroplast transit peptide coding region from the pea Rubisco small subunit gene (14) was placed upstream of the DMO coding region. The transit peptide coding sequence carried on a $\mathrm{Bgl}$ II and EcoR I fragment was cloned into the BamH I and EcoR I sites of the pBluescript II KS+ vector. This construct was used as the template in a PCR reaction that inserted an Nco I site 
at both the $3^{\prime}$ and the $5^{\prime}$ ends of the transit peptide sequence (Tra-F 5'ataaggttgatatcgaattcccat $-3^{\prime}$; Tra-R 5'- agatctagaggatccatggcttct $\left.-3^{\prime}\right)$. The amplified product was cloned into the Nco I site of the pRLT2 vector so that the transit peptide sequence was directly upstream and in frame with the coding region of the DMO gene. Correct orientation of the transit peptide coding sequence was confirmed by DNA sequencing. A cassette consisting of the TEV leader, transit peptide region and DMO DNA coding sequences was excised from the pRTL2 vector with Xho I and Xba I and cloned into the pKLP36 vector (9) using the same restriction sites for linking the cassette to a PCISV promoter and PsRbcS2-E9 poly A sequence. The new vector was labeled as pKLP36-TEV-TPDMOc (ATCC deposit PTA-7357) and used for transforming tobacco, Arabidopsis and tomato plants. For soybean transformation, the DMOc cassette was cut out of the pKLP36-TEV-TP-DMOc as an EcoR I/Cla I segment and cloned into pPZP101 (15) for obtaining right and left T-DNA borders. This vector (pPZP101+DMOc cassette) was then cut with Scal and the DMOc cassette was cloned into the binary vector pPTN200 (see below), a derivative of pPZP201 (15), that contains a bar cassette flanked by left and right T-DNA borders and allows for selection of regenerating transformants in the presence of the herbicide, Basta. The new two T-DNA binary vector was designated pPTN348 and used for soybean transformation. The vector pPTN200 was prepared by first cloning a nos promoter-bar element from pGPTV-bar (16) as a Pstl/BamHI segment into pPZP201 (15). The resultant plasmid was named pPTN193. The nos terminator from $p E 7113-G U S$ (17) was cloned into pPTN193 downstream of the nos promoter-bar element to obtain the bar cassette.

Plant Transformation: The genetically engineered DMO gene cassette in the binary vector, pKLP36, was introduced into $A$. tumefaciens strain C58C1 containing the disarmed Ti plasmid pMP90 (18) by triparental mating (19). The resultant transconjugants were used in tobacco (cv Xanthi) and tomato (cv Rutgers) transformation experiments using the leaf disc protocol described by Horch et al (20). Arabidopsis thaliana was transformed by the floral dip technique $(21,22)$. Transformation of soybean varieties, Thorne and Ne3001, utilized $A$. tumefaciens EHA101 transconjugants and were carried out by cotyledonary-node Agrobacterium-mediated transformation system (23).

For chloroplast genome transformation, the DMOc gene coding region was placed downstream of the psbA gene promoter in pFMDV1 [derived by Dr. Lori Allison from vectors developed by the laboratory of Dr. Pal Maliga (24)] to produce chloroplast transformation vector pDMO1 (Figure S5). The pDMO1 vector was used to transform Nicotiana tabacum using previously published procedures (25) for chloroplast genome transformation and for selection of transgenic tobacco plants homoplastidic for the DMO gene.

Analysis of Transgenic Plants: For DNA blot analyses, total genomic DNA was isolated from plant tissue using a modified protocol of Brutnell and Dellaporta (26). The genomic DNA (5 $\mu$ g) was digested overnight and purified by gel electrophoresis and transferred to a positively charged nylon membrane 
(Roche). A DNA probe prepared using a portion of the cloned DMO gene was labeled using digoxigenin (DIG) according to the protocol described in the DIG Application Manual (Roche). Two primers were used to produce a DIG-labeled probe: DMO forward: 5'-GCTGCCCGAGGAACTGTCCGAAAAG-3' and DMO reverse: 5'-CGACGACGACCTTGTCCTCCTTGA-3'. For RNA blot analyses, total RNA was isolated from transgenic and nontransgenic plants using the protocol of Buhr et al. (27). The hybridization probe employed was the same as that used for DNA blot analysis. For protein blot analyses, leaves were collected (0.5-1.0g), ground in the presence liquid nitrogen to a fine powder. The powder was resuspended in $4 \mathrm{ml}$ protein extraction buffer [50mM MES buffer, $(\mathrm{pH} 6.8), 2 \%$ polyvinylpolypyrrolidone (PVPP), 5mM dithiothreitol, 0.5mM PMSF, $0.125 \mu \mathrm{l}$ Protease inhibitor cocktail, $5 \%$ glycerol] and placed in a $30 \mathrm{ml}$ centrifuge tube on ice. Protein samples were placed on a shaker at $4^{\circ} \mathrm{C}$ and shaken at $250-300 \mathrm{rpm}$ for 1-2 hours. Samples were then centrifuged at $20,000 \times \mathrm{g}$ for 20 minutes at $4^{\circ} \mathrm{C}$. The supernatant was then poured off, quick frozen using liquid nitrogen and stored at $-80^{\circ} \mathrm{C}$.

Treatment of Transgenic and Nontransgenic Plants with Dicamba: Plants were sprayed by technicians in the Agronomy Department greenhouses with solvent or commercial grade dicamba (Clarity; BASF) using a compressed air, motor-driven, track sprayer with a flat-fan $8002 \mathrm{E}$ nozzle traveling at $1.87 \mathrm{mph}$. Additives included $28 \%$ urea ammonium nitrate at $1.25 \% \mathrm{v} / \mathrm{v}$ and nonionic surfactant at $1.0 \% \mathrm{v} / \mathrm{v}$. The solution containing dicamba at various concentrations was applied at $182 \mathrm{~L} / \mathrm{ha}$ (40 gallons per acre). Soybean field plantings were sprayed with Clarity herbicide at $2.8 \mathrm{~kg} / \mathrm{ha}(2.5 \mathrm{lb} / \mathrm{ac})$.

Dicamba Monooxygenase Assays: Isolation, purification and assays of dicamba monooxygenase with nonlabelled and ${ }^{14} \mathrm{C}$-labelled dicamba were as previously described $(6,7)$. Spinach (Spinica oleracea) and Clostridium pasteurianum ferredoxins and spinach ferredoxin oxidoreductase were purchased from Sigma-Aldrich.

Herbicide Resistance Nomenclature: In accordance with suggested nomenclature ( 3 and www.weedscience.org), the term, "resistance", and not the word, "tolerance", has been used in this study (i.e., "Resistance is defined as the inherited ability of a plant to survive and reproduce following exposure to a dose of herbicide normally lethal to the wild type. In a plant, resistance may be naturally occurring or induced by such techniques as genetic engineering or selection of variants produced by tissue culture or mutagenesis.") 


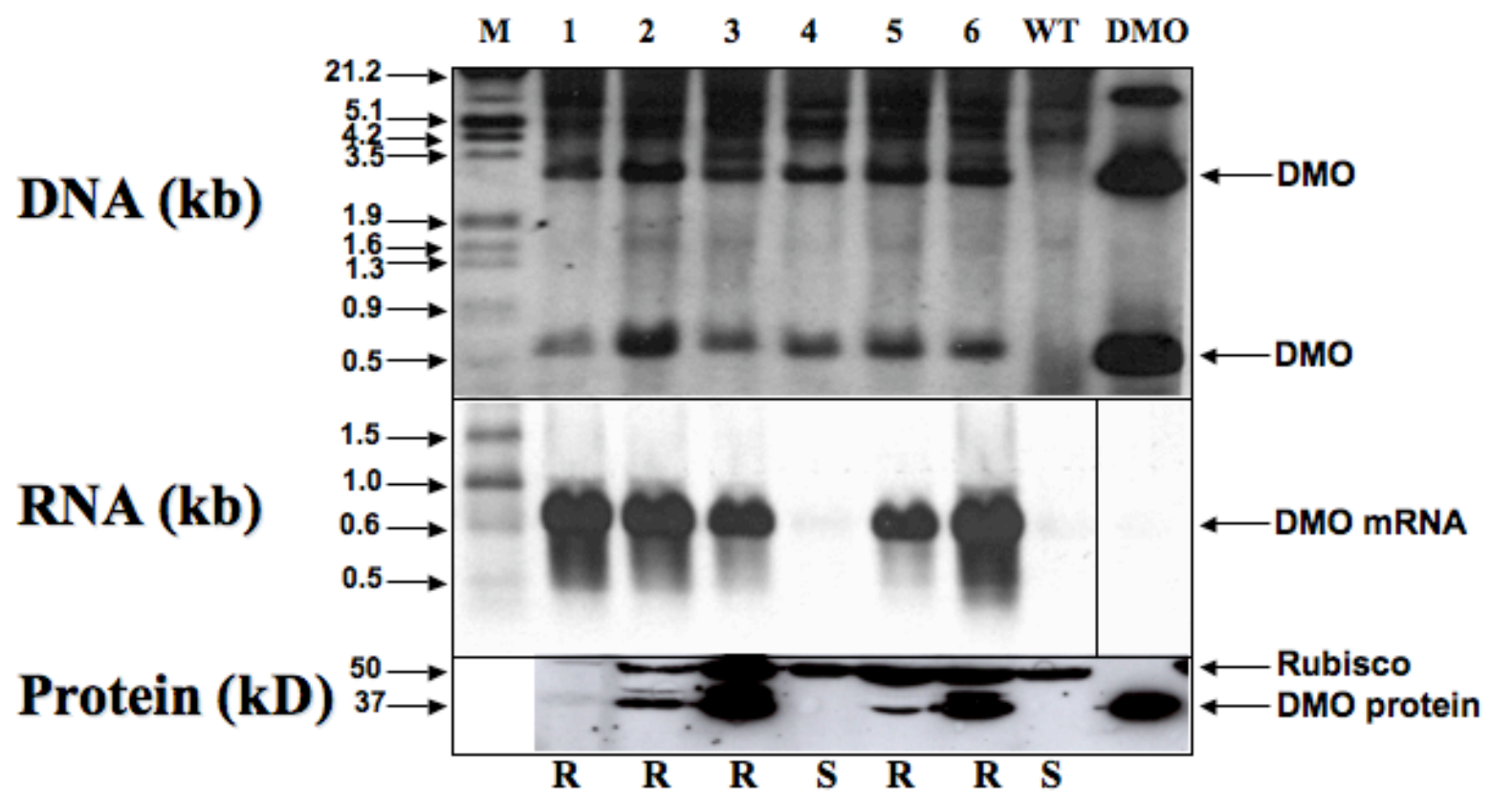

Figure S1. DNA, RNA and protein blots demonstrating the presence and expression of the genetically engineered $\mathrm{DMO}$ gene in $\mathrm{T}_{1}$ generation transgenic tobacco plants. Lanes 1 through 6 depict blots of DNA (top panel), mRNA (middle panel) and DMO species (bottom panel) extracted from various $\mathrm{T}_{1}$ generation transgenic tobacco plants. Extracts from a nontransgenic tobacco plant are depicted in lane 7 (WT) while lane 8 exhibits a restriction enzyme (Mls I)-digestion product of the cloned DMO gene construct (top panel) and the $\sim 37$ $\mathrm{kDa} \mathrm{DMO}$ enzyme overproduced in $E$. coli (bottom panel). In the protein blot, the $\sim 55 \mathrm{kDa}$ large subunit of Rubisco was detected by Rubisco antibodies in the DMO antisera and served as an internal standard to compare total protein loads in each lane. Equal amounts of RNA were loaded in each lane of the RNA blot as judged by ethidium bromide staining of a duplicate gel (data not shown). Arrows point to DMO DNA, mRNA and protein species in the respective panels. $\mathrm{M}$, DNA and RNA size markers. R, plants resistant to treatment with dicamba at $0.56 \mathrm{~kg} / \mathrm{ha}$; S, plants sensitive to treatment with dicamba at $0.56 \mathrm{~kg} / \mathrm{ha}$. 


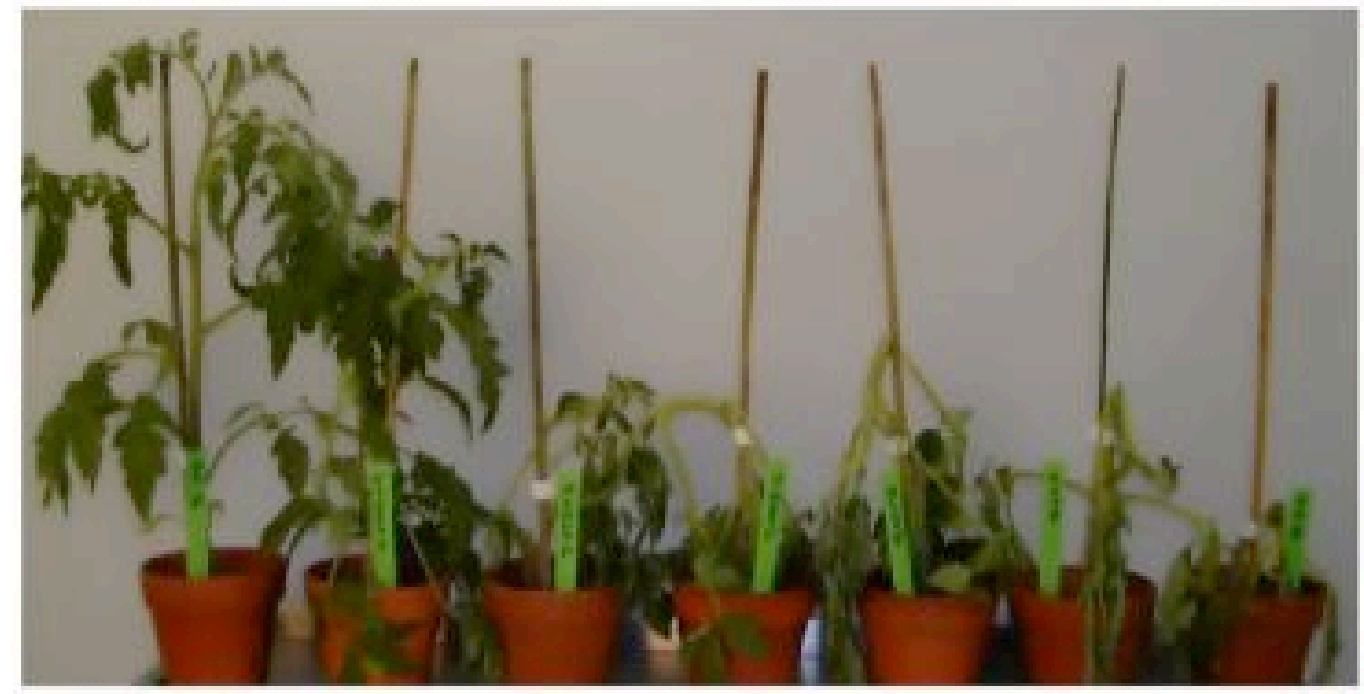

\section{A $\quad$\begin{tabular}{lllllll}
0 & 0.018 & 0.036 & 0.072 & 0.144 & 0.286 & 0.56 \\
\hline
\end{tabular}}

\section{Concentration of Dicamba $(\mathrm{kg} / \mathrm{ha})$}

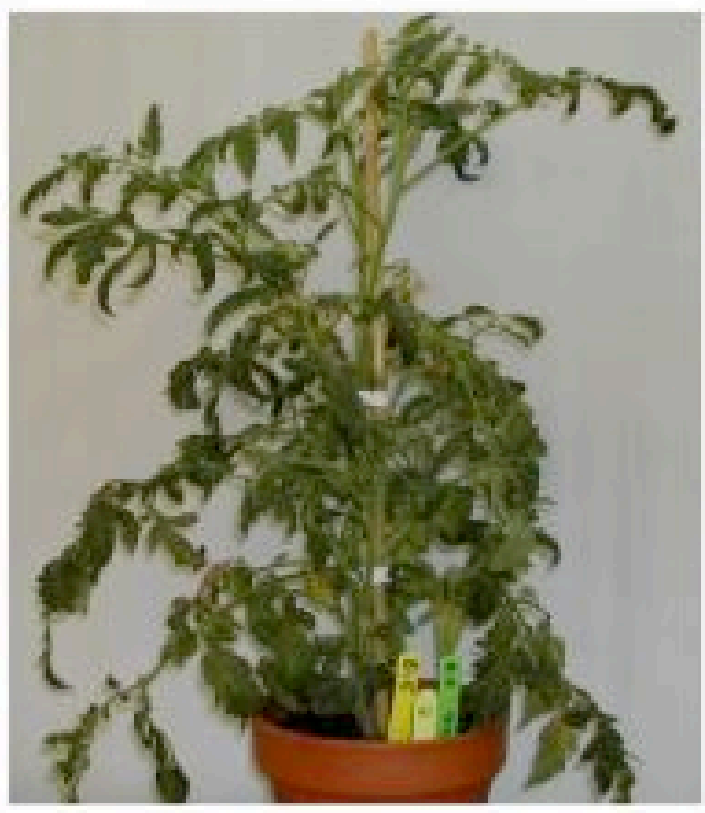

B

Figure S2. Effects of dicamba treatments on nontransgenic (A) and transgenic (B) tomato plants. (A) Nontransgenic plants treated with no dicamba (plant on left) and treated with increasing amounts of dicamba from $0.018 \mathrm{~kg} / \mathrm{ha}(0.016$ $\mathrm{lb} /$ acre) to $0.56 \mathrm{~kg} / \mathrm{ha}(0.5 \mathrm{lb} / \mathrm{acre})$. (B) $\mathrm{A} \mathrm{T}_{1}$ generation transgenic tomato plant carrying the DMO gene and treated initially with dicamba at a level of $0.56 \mathrm{~kg} / \mathrm{ha}$ and, subsequently, at a rate of $5.6 \mathrm{~kg} / \mathrm{ha}$. 

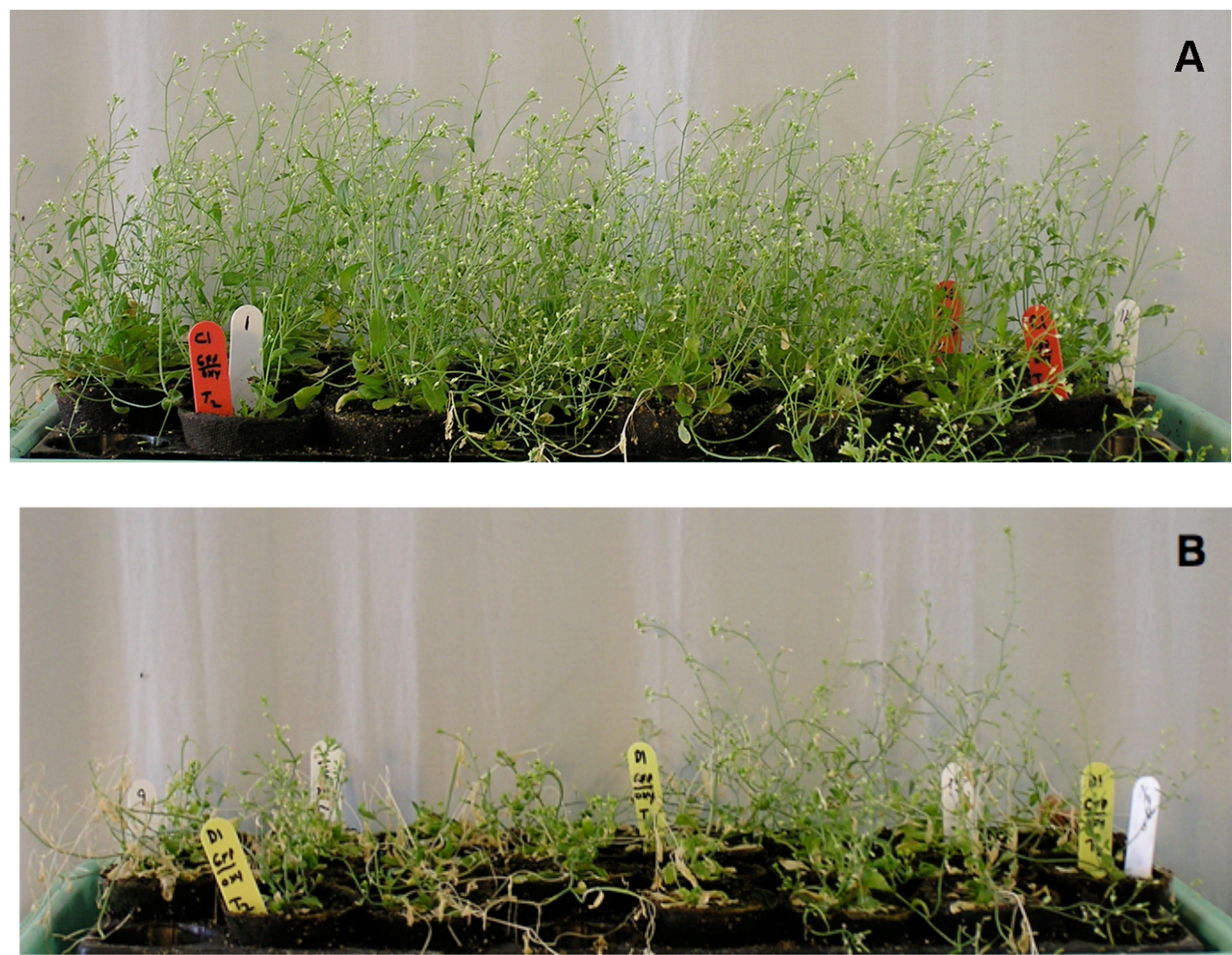

Figure S3. Effects of dicamba treatments on transgenic and nontransgenic Arabidopsis thaliana plants. A) Transgenic Arabidopsis thaliana plants containing the dicamba-tolerance gene treated with dicamba at a level of 1.12 $\mathrm{kg} / \mathrm{ha}$. B) Nontransgenic Arabidopsis thaliana plants treated with dicamba at $1.12 \mathrm{~kg} / \mathrm{ha}$. 


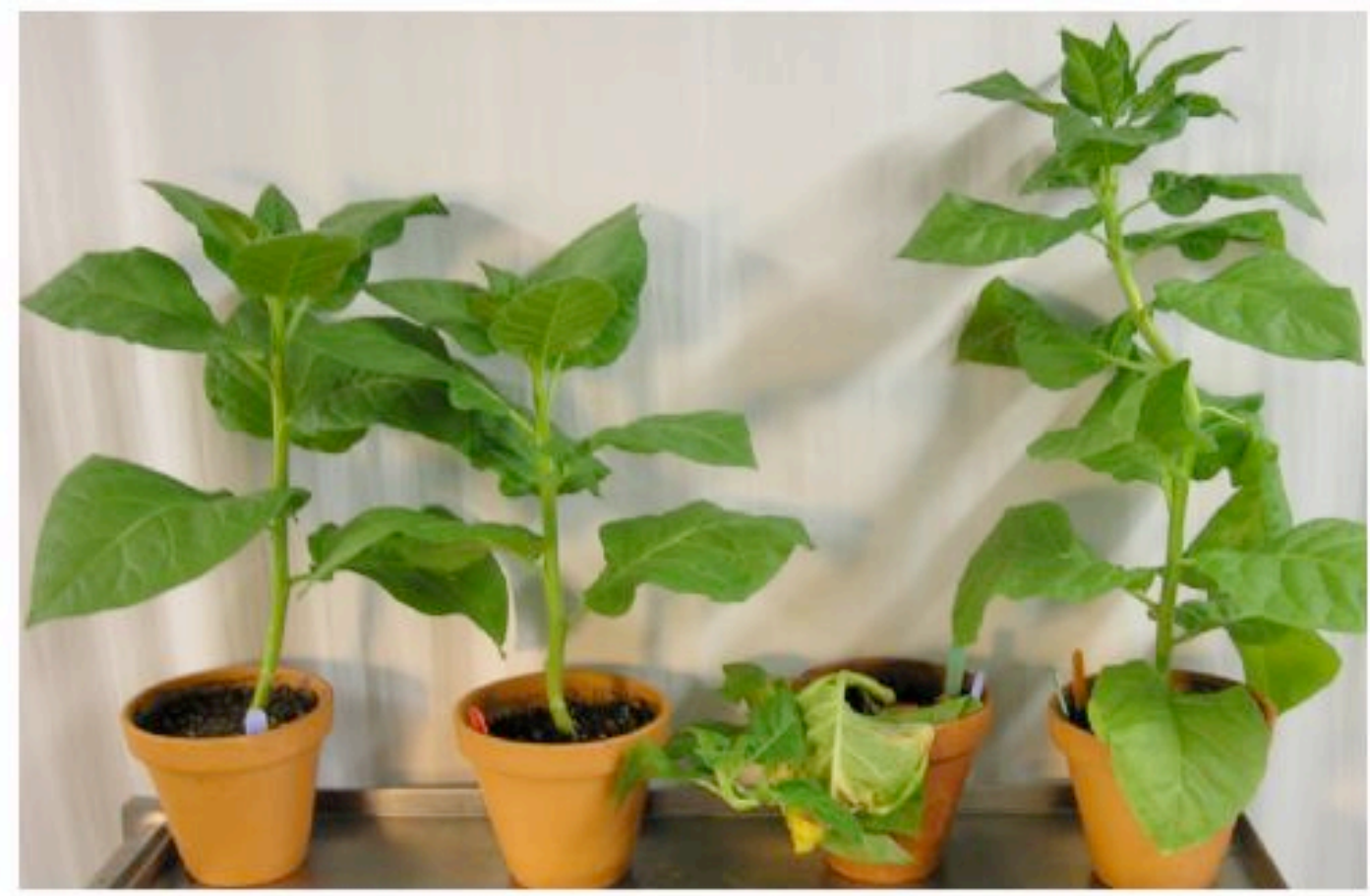

Figure S4. Effect of treatment with dicamba at $2.2 \mathrm{~kg} / \mathrm{ha}$ on two transgenic tobacco plants (right) carrying the DMO gene lacking a chloroplast transit peptide coding sequence. The third plant from the left displays initial major damage, but at least partial recovery two weeks after treatment (emerging green shoot). The transgenic plant on the right displays little, if any, damage from dicamba treatment. The two plants to the left were not treated with dicamba and represent a nontransgenic plant (left) and a transgenic plant (second from left). 


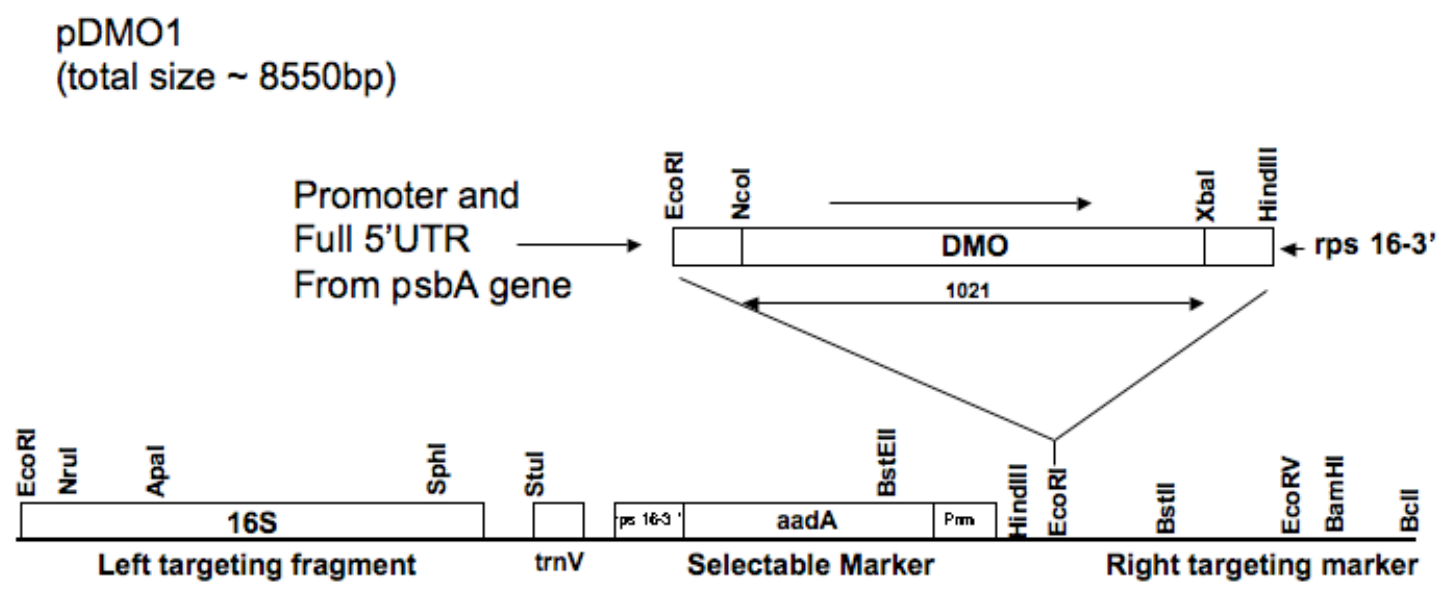

Figure S5. Construct of dicamba monooxygenase gene genetically engineered for homologous recombination and expression in tobacco chloroplasts. A digoxigenin-labeled probe produced by PCR from the left targeting fragment was used to detect DNA fragments in the DNA blots of Figure S6. 

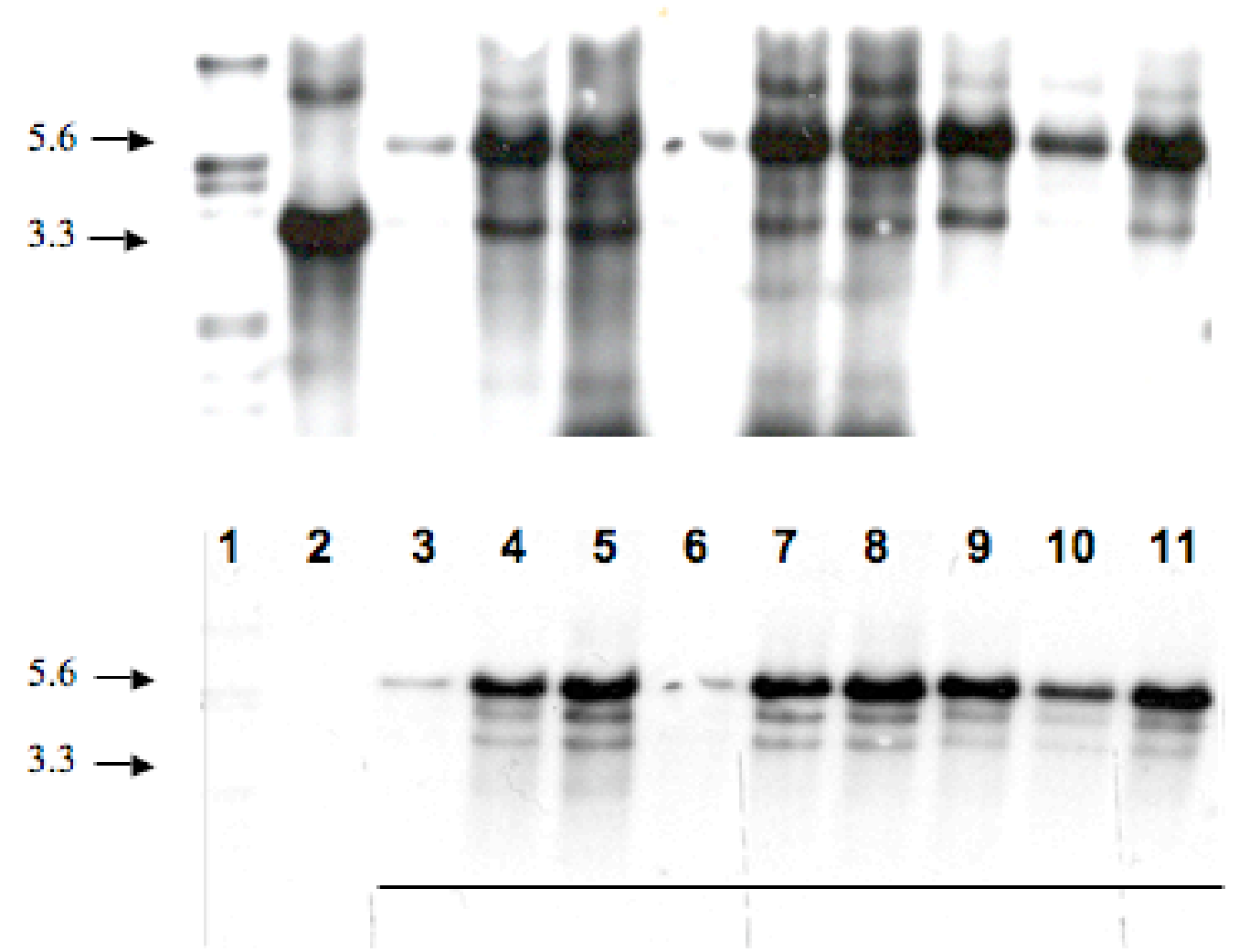

M WT

TRANSGENIC

Figure S6. Demonstration of the homoplastidic status of chloroplast genomes of transgenic tobacco lines transformed with a dicamba monooxygenase gene designed for homologous recombination and expression in tobacco chloroplasts. DNA blots: Lane 1 contains a set of size-marker DNA fragments. Lane 2 contains DNA from nontransgenic tobacco plants. Lanes 3 through 11 contain DNA isolated from transgenic plants soon after the first round of selection and regeneration in the presence of spectinomycin $(A)$ and progeny of the same plants after several rounds of selection and regeneration during which apparent homoplastidity of the chloroplast genome was obtained (B). DNA for DNA blot analyses was isolated from transgenic and nontransgenic plants and subjected to digestion with BamH I. After electrophoretic separation, DNA fragments were blotted to nylon membranes and hybridized with a labeled DNA fragment complementary to the "left targeting sequence" of the chloroplast genome transformation vector (Figure S5). The $5.6 \mathrm{~kb}$ DNA band corresponds to the chloroplast DNA fragment containing the DMO gene and the $3.3 \mathrm{~kb}$ band corresponds to the homologous native chloroplast band lacking an inserted DMO gene construct (see Figure S5). 


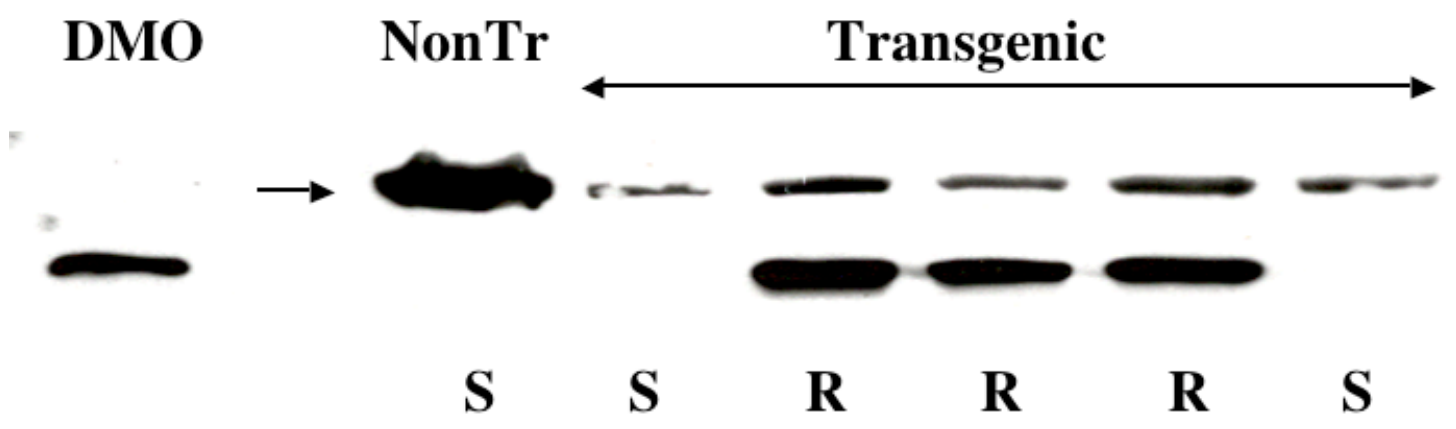

Figure S7. Expression of DMO and sensitivity to treatment with dicamba in nontransgenic tobacco plants and transgenic tobacco plants containing the DMO gene in the chloroplast genome. Protein blot probed with DMO antibodies: Lane 1 contains purified DMO from P. maltophilia, strain DI-6. Lane 2 is blank and lane 3 contains protein extracts from a nontransgenic tobacco plant. Lanes 4 and 8 contain proteins isolated from "false-positive" tobacco plants displaying antibiotic resistance during selection on spectinomycin, but which lacked an intact DMO gene. Lanes 5, 6 and 7 contain extracts of transgenic plants expressing DMO encoded by a DMO gene integrated into the chloroplast genome. $\mathrm{S}=$ plants sensitive to treatment with dicamba at $0.56 \mathrm{~kg} / \mathrm{ha} ; \mathrm{R}=$ plants resistant to treatment with dicamba at $5.6 \mathrm{~kg} / \mathrm{ha}$. Nearly equal amounts of extracts were loaded into lanes 4 through 8 as judged by the amount of Rubisco large subunit protein (arrow) detected with anti-Rubisco antibodies, while significantly more protein from the nontransgenic plant was loaded into lane 3 to ensure that the DMO antibodies were not detecting an endogenous protein of the same molecular size as DMO. 


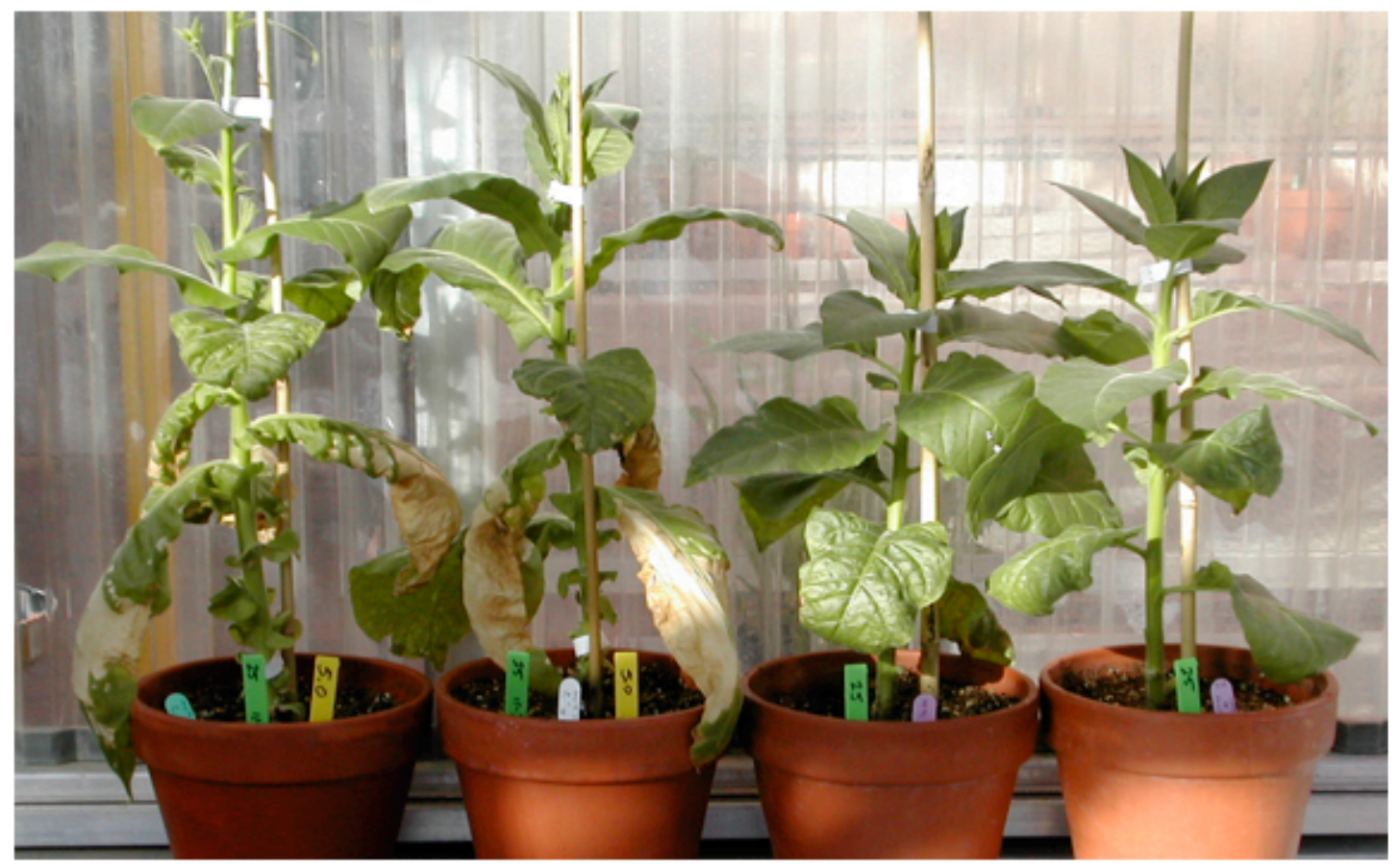

Figure S8. $\mathrm{T}_{1}$ generation homoplastidic transgenic tobacco plants containing a chloroplast-encoded dicamba monooxygenase gene and treated with dicamba at a level of $28 \mathrm{~kg} / \mathrm{ha}$. (Plants 1 and 2 and plants 3 and 4 were derived from two independently transformed $T_{0}$ plants.) 


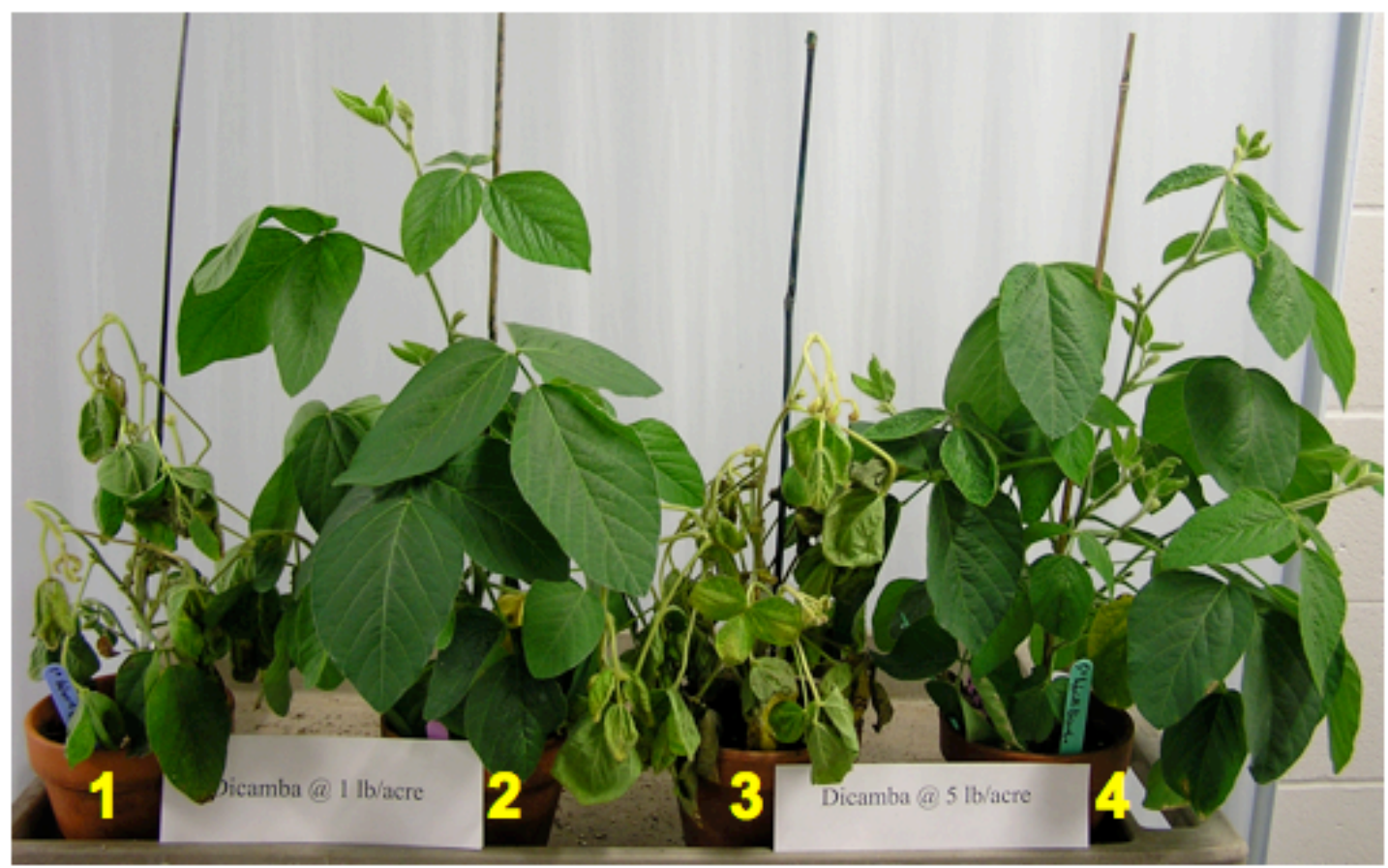

Figure S9. Effects of dicamba treatments under greenhouse conditions on nontransgenic soybean plants and transgenic plants containing the genetically engineered dicamba monooxygenase gene. Nontransgenic plants ( 1 and 3 ) and transgenic soybean plants treated with dicamba at $1.12 \mathrm{~kg} / \mathrm{ha}$ (plants 1 and 2) and $5.6 \mathrm{~kg} / \mathrm{ha}$ (plants 3 and 4); pictured one week after spraying. 


\section{Supplementary Online Material Tables:}

\section{Degradation of Dicamba}

\section{Type of Reaction}

$(\text { Ferr }+ \text { Red })_{\mathrm{DI}-6}+\mathrm{NADH}$

$(\mathrm{Oxy}+\mathrm{Ferr}+\mathrm{Red})_{\mathrm{DI}-6}+\mathrm{NADH}$

$(\mathrm{Oxy})_{\mathrm{DI}-6}+(\mathrm{Ferr})_{\text {spinach }}+(\text { Ferr:Oxidored })_{\text {spinach }}+\mathrm{NADPH}$

$(\mathrm{Oxy})_{\mathrm{DI}-6}+(\text { Ferr:Oxidored })_{\text {spinach }}+\mathrm{NADPH}$

$(\mathrm{Oxy})_{\mathrm{DI}-6}+(\text { Ferr })_{\text {spinach }}+(\text { Ferr:Oxidored })_{\text {spinach }}+$ No NADPH

$(\mathrm{Oxy})_{\mathrm{DI}-6}+(\text { Ferr })_{\text {clostridium }}+(\text { Ferr:Oxidored })_{\text {spinach }}$ +NADPH

$(\text { Ferr })_{\text {clostridium }}+(\text { Ferr:Oxidored })_{\text {spinach }}+\mathrm{NADPH}$

\section{Degradation of Dicamba}

(\%)

80

86

83

ND

ND

82

\section{Formation of DCSA}

\begin{tabular}{lc}
\hline \hline \multicolumn{1}{c}{ Type of Reaction } & Formation of DCSA (\%) \\
$(\text { Ferr }+ \text { Red })_{\mathrm{DI}-6}+\mathrm{NADH}$ & $\mathrm{ND}$ \\
$(\text { Oxy }+ \text { Ferr + Red })_{\mathrm{DI}-6}+\mathrm{NADH}$ & 100 \\
$(\text { Oxy })_{\mathrm{DI}-6}+(\text { Ferr })_{\text {spinach }}+(\text { Ferr:Oxidored })_{\text {spinach }}+\mathrm{NADPH}$ & 95 \\
$(\mathrm{Oxy})_{\mathrm{DI}-6}+(\text { Ferr:Oxidored })_{\text {spinach }}+\mathrm{NADPH}$ & 2.5 \\
$(\text { Oxy })_{\mathrm{DI}-6}+(\text { Ferr })_{\text {spinach }}+(\text { Ferr:Oxidored })_{\text {spinach }}+$ No NADPH & 1.2 \\
$(\text { Oxy })_{\mathrm{DI}-6}+(\text { Ferr })_{\text {clostridium }}+(\text { Ferr:Oxidored })_{\text {spinach }}+\mathrm{NADPH}$ & 90 \\
$(\text { Ferr })_{\text {clostridium }}+(\text { Ferr:Oxidored })_{\text {spinach }}+\mathrm{NADPH}$ & 1.5 \\
\hline \hline
\end{tabular}

ND, Not Detected

Table S1. Purified dicamba monooxygenase can utilize reduced spinach (Spinica oleracea) chloroplast ferredoxin or reduced Clostridium pasteurianum ferredoxin as sources of electrons to catalyze the conversion in vitro of dicamba to 3,6-dichlorosalicylic acid (DCSA). OxyDI-6: dicamba Monooxygenase (DMO); $(\mathrm{Oxy}+\mathrm{Ferr}+\mathrm{Red})_{\mathrm{DIC}}$ : the oxygenase, ferredoxin and reductase components of

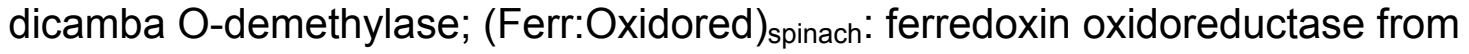
spinach. 
Quantification of DMO in leaves of transgenic tobacco lines

\begin{tabular}{|l|l|l|l|}
\hline & $\begin{array}{l}\text { Oxygenase in } \\
\text { total soluble } \\
\text { protein }(\%)\end{array}$ & $\begin{array}{l}\text { Oxygenase } \\
\text { quantity } \\
\left(\mu \mathrm{g} \cdot \mathrm{g}^{-1} \mathrm{~F} . \mathrm{wt}\right)\end{array}$ & $\begin{array}{l}\text { Oxygenase } \\
\text { quantity } \\
\left(\mu \mathrm{\mu g} \cdot \mathrm{g}^{-1} \mathrm{D} . \mathrm{wt}\right)\end{array}$ \\
\hline $\begin{array}{l}\text { Control } \\
\text { (nontransformed) }\end{array}$ & nondetectable & nondetectable & nondetectable \\
\hline $\begin{array}{l}\text { Chloroplast } \\
\text { transformation }\end{array}$ & $0.636( \pm 0.064)$ & $197.5( \pm 3.85)$ & $1978.6( \pm 38.60)$ \\
\hline Nuclear transformation & $0.014( \pm 0.003)$ & $4.9( \pm 0.95)$ & $48.6( \pm 9.50)$ \\
\hline $\begin{array}{l}\text { Nuclear transformation } \\
+ \text { chloroplast transit } \\
\text { peptide }\end{array}$ & $0.027( \pm 0.003)$ & $9.6( \pm 1.18)$ & $94.26( \pm 11.63)$ \\
\hline
\end{tabular}

Table S2. Estimates of DMO amounts and activities in plants producing DMO from nuclear or chloroplast genomes. A tissue sample from the eighth leaf from bottom of tobacco plant was harvested 38 days after planting of seeds. DMO levels in leaf extracts were estimated on protein blots using DMO antibodies and highly purified DMO overproduced in E. coli as standards for quantification. Control: nontransgenic plants; Chloroplast transformation: homoplastidic plants carrying the DMO gene incorporated into the chloroplast genome; Nuclear transformation: plants carrying the DMO gene in the nuclear genome; Nuclear transformation + chloroplast transit peptide: plants carrying a nuclear DMO gene containing coding sequence for an $\mathrm{N}$-terminal chloroplast transit peptide. ( $n=3$ independent plants/measurement) 


\begin{tabular}{|c|c|c|c|c|c|c|c|}
\hline & 1 & 2 & 3 & 4 & 5 & 6 & 7 \\
\hline Group & E-Selfed & |-Selfed & J-Selfed & WT\#1 & WT\#2 & $\mathrm{H \# 1}$ & H\#10 \\
\hline Resistant & 71 & 92 & 100 & 0 & 0 & 32 & 31 \\
\hline Sensitive & 32 & 36 & 37 & 32 & 32 & 0 & 0 \\
\hline Totals & 103 & 128 & 137 & 32 & 32 & 32 & 31 \\
\hline Percent - R & 68.9 & 71.9 & 73 & 0 & 이 & 100 & 100 \\
\hline Percent - S & 31.1 & 28.1 & 27 & 100 & 100 & 0 & 0 \\
\hline Expected - R & 77.25 & 96 & 102.75 & & & & \\
\hline Expected - S & 25.75 & 32 & 34.25 & & & & \\
\hline Chi. Sq. R & 0.506 & 0.167 & 0.074 & & & & \\
\hline Chi. Sq. S & 1.517 & 0.500 & 0.221 & & & & \\
\hline Total Chi. Sq. & 2.023 & 0.667 & 0.294 & & & & \\
\hline p value & $>0.10$ & $>0.25$ & $>0.25$ & & & & \\
\hline Ratio & $3: 1$ & $3: 1$ & $3: 1$ & & & & \\
\hline Group & WTxE & Whtx| & WTxJ & & & & \\
\hline Resistant & 15 & 68 & 67 & & & & \\
\hline Sensitive & 17 & 59 & 59 & & & & \\
\hline Totals & 32 & 127 & 126 & & & & \\
\hline Percent - R & 46.9 & 53.5 & 53.2 & & & & \\
\hline Percent - S & 53.1 & 46.5 & 46.8 & & & & \\
\hline Expected - R & 16 & 63.5 & 63 & & & & \\
\hline Expected - S & 16 & 63.5 & 63 & & & & \\
\hline Chi. Sq. - R & 0.063 & 0.319 & 0.254 & & & & \\
\hline Chi. Sq. - S & 0.063 & 0.319 & 0.254 & & & & \\
\hline Total Chi Sq. & 0.125 & 0.638 & 0.508 & & & & \\
\hline p value & $>0.25$ & $>0.25$ & $>0.25$ & & & & \\
\hline Ratio & 1:1 & $1: 1$ & 1:1 & & & & \\
\hline
\end{tabular}

Table S3. Inheritance of the dicamba-resistance trait. Three $T_{1}$ generation plants obtained from selfing of original $T_{0}$ transformed tobacco plants were self fertilized (top row, columns 1, 2, and 3) or crossed with parental wild-type tobacco plants (bottom row, columns 1, 2, and 3). Progeny of the self fertilized and wild-type crosses were sprayed at the five-leaf stage of development and scored for resistance (healthy and growing) or sensitivity (rapidly dying) to applications of dicamba at $0.56 \mathrm{~kg} / \mathrm{ha}$. As controls showing the response or nonresponse to dicamba treatments, two sets of parental wild-type tobacco plants (columns 4 and 5 ) and two sets of homozygous transgenic plants (H\#1,

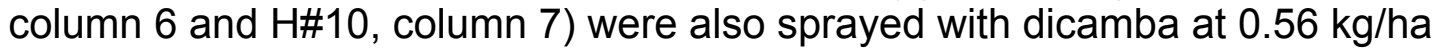
and scored for resistance or sensitivity. 